\title{
Influence of wall materials on the microencapsulation of pequi oil by spray drying
}

\author{
Influência dos materiais de parede na \\ microencapsulação de óleo de pequi através da secagem \\ por atomização
}

\begin{abstract}
Fabiana Helen dos Santos ${ }^{1 *}$ (D), Bianca Marise Pereira e Silveira1, Lourena Lopes de Souza ${ }^{1}$, Anna Karolina Cruz Duarte ${ }^{1}$, Milton Cosme Ribeiro², Keyla Carvalho Pereira ${ }^{1}$, Joyce Maria Gomes da Costa ${ }^{1}$
\end{abstract}

\author{
${ }^{1}$ Universidade Federal dos Vales Jequitinhonha e Mucuri (UFVJM), Instituto de Ciência e Tecnologia, \\ Diamantina/MG - Brasil \\ ${ }^{2}$ Superintendência de Saúde de Diamantina, Secretaria de Saúde do Estado de Minas Gerais, \\ Diamantina/MG - Brasi
}

${ }^{*}$ Corresponding Author: Fabiana Helen dos Santos, Universidade Federal dos Vales Jequitinhonha e Mucuri (UFVJM), Instituto de Ciência e Tecnologia, Rodovia MG 367, km 583, 5000, Alto da Jacuba, CEP: 39100-000, Diamantina/MG - Brasil, e-mail: bianahelen@yahoo.com.br

Cite as: Santos, F. H., Silveira, B. M. P., Souza, L. L., Duarte, A. K. C., Ribeiro, M. C., Pereira, K. C., \& Costa, J. M. G. (2020). Influence of wall materials on the microencapsulation of pequi oil by spray drying. Brazilian Journal of Food Technology, 23, e2019132. https://doi.org/10.1590/1981-6723.13219

\begin{abstract}
The aim of this study was to assess the influence of the wall materials on the microencapsulation of pequi oil. An emulsion containing pequi oil in the oil phase was microencapsulated by spray drying process at $120^{\circ} \mathrm{C}$ using gum Arabic, maltodextrin, or a $25: 75(\mathrm{w} / \mathrm{w})$ mixture of gum Arabic and maltodextrin as wall material. The emulsions were characterized for droplet size, Polydispersity Index (PDI), and zeta potential. Pequi oil microparticles were analyzed for moisture content, water activity, wettability, encapsulation efficiency, antioxidant capacity, and color. Ultrastructural examination was performed by Scanning Electron Microscopy (SEM). The Droplet Size Distribution (DSD) of the emulsions exhibited a relatively wide size distribution $(2.67$ to $8.96 \mu \mathrm{m})$ and high PDI (> 0.3). Smooth microparticles with high encapsulation efficiency $(79.17 \%$ to $84.20 \%)$, and good antioxidant capacity (28.20 to $28.71 \mu \mathrm{mol}$ Trolox equivalents/g dry extract) were obtained. Microparticles prepared using gum Arabic as wall material had higher antioxidant capacity than that prepared with maltodextrin. All microparticles had satisfactory encapsulation efficiency, water activity, moisture content, and wettability. These results indicate that pequi oil microparticles have characteristics that can contribute to good stability during storage and handling of encapsulated oil. Therefore, pequi oil can be successfully encapsulated by spray drying using gum Arabic, maltodextrin, or 25:75 (w/w) mixture of gum Arabic and maltodextrin as wall materials, but the physicochemical properties of microparticles vary with wall material composition.
\end{abstract}

Keywords: Caryocar brasiliense; Pulverization; Encapsulating agents; Characterization; Morphology; Microparticle. 


\section{Resumo}

O objetivo deste estudo foi avaliar a influência dos tipos de materiais de parede no processo de microencapsulação de óleo de pequi. A emulsão contendo óleo de pequi em sua fase de óleo foi seca por pulverização a $120^{\circ} \mathrm{C}$, usando goma arábica, maltodextrina ou uma mistura de $25: 75$ (g/g) de goma arábica e maltodextrina como materiais de parede. As emulsões foram caracterizadas pelo tamanho de gota, índice de polidispersão e potencial zeta. As micropartículas de óleo de pequi foram analisadas quanto ao conteúdo de umidade, atividade de água, molhabilidade, eficiência de encapsulação, capacidade antioxidante e cor. A avaliação ultra estrutural foi realizada por microscopia eletrônica de varredura. O tamanho de gota das emulsões exibiu uma distribuição de tamanho relativamente ampla (2.67 a $8.96 \mu \mathrm{m})$ e alto índice de polidispersão $(>0,3)$. Foram obtidas micropartículas lisas com alta eficiência de encapsulação $(79,17 \%$ a $84,20 \%)$ e boa capacidade antioxidante $(28,20$ a $28,71 \mu \mathrm{mol}$ equivalente de Trolox/g extrato seco). As micropartículas preparadas usando goma arábica como material de parede demonstraram ter maior capacidade antioxidante que as produzidas com maltodextrina. Todas as micropartículas apresentaram valores satisfatórios de conteúdo de umidade, atividade de água e molhabilidade. Esses resultados indicam que as micropartículas de óleo de pequi apresentam características que podem contribuir para uma boa estabilidade durante a estocagem e manuseio do óleo encapsulado. Portanto, o óleo de pequi pode ser encapsulado com sucesso por pulverização utilizando goma arábica, maltodextrina ou a mistura de 25:75 (g/g) de goma arábica e maltodextrina como materiais de parede, no entanto as propriedades físico-químicas das micropartículas podem variar de acordo com a composição destes materiais de parede.

Palavras-chave: Caryocar brasiliense; Pulverização; Agentes encapsulantes; Caracterização; Morfologia; Micropartícula.

\section{Introduction}

The Brazilian Cerrado is known for its rich diversity of fruits of vibrant colors, peculiar flavors, and high nutritional and medicinal values. Pequi (Caryocar brasiliense Camb.), an oleaginous fruit from the Cerrado, has high antioxidant capacity and high content of fat-soluble vitamins, saturated and monounsaturated fatty acids, carotenoids, and phenolic acids (Mendonça et al., 2017; Pessoa et al., 2015). Because pequi is a seasonal fruit and is not available throughout the year, the fruits must be processed for oil extraction. Pequi oil is widely used in traditional dishes and sauces (Aguilar et al., 2012; Santana et al., 2014). The oil is rich in saturated and monounsaturated fatty acids, and also in vitamins $\mathrm{A}$ and $\mathrm{E}$, which are sensitive to heat, oxygen, light and humidity.

Different techniques have been used to preserve the stability and biological properties of pequi oil. For instance, spray drying can afford microparticles with good quality and stability, low water activity, and easy handling and storage (Carneiro et al., 2013). This process involves the formation of an emulsion, solution or suspension containing the core and wall material, followed by atomization in a drying chamber with circulating hot air (Carvalho et al., 2014).

The wall material influences the physicochemical and storage characteristics of microparticles, such as oxidative stability, particle size distribution, density, and morphology (Carneiro et al., 2013). Maltodextrin and gum Arabic are the two most common wall materials used in spray drying (Pereira et al., 2018). The first one is the major material used in microencapsulation of food ingredients, with low cost, neutral aroma and taste, whereas the second also presents many desirable characteristics, as a good encapsulating agent, with the high solubility, low viscosity and good emulsifying properties (Carneiro et al., 2013; Di Battista et al., 2015; Gupta et al., 2015).

This study aimed to assess the effects of encapsulating agent (gum Arabic, maltodextrin, or a mixture of both agents) on the physicochemical and biological properties of spray-dried pequi oil, 
in order to find the agent that can keep the best characteristics of the active material. Encapsulation efficiency, antioxidant capacity, zeta potential, polydispersity index, color, moisture content, particle size, water activity, morphology, and wettability were evaluated.

\section{Material and methods}

\subsection{Material}

Pequi oil was purchased at the Central Market of Belo Horizonte (Minas Gerais, Brazil). Gum Arabic was obtained from Dinâmica Química Contemporânea (Indaiatuba, São Paulo, Brazil) and maltodextrin DE-05 from Ingredion (Balsa Nova, Paraná, Brazil).

\subsection{Experimental procedure}

Pequi oil microparticles were prepared using different proportions of gum Arabic and maltodextrin as wall material (Table 1).

Table 1. Proportion of gum Arabic and maltodextrin used as wall material to microencapsulate pequi oil by spray drying.

\begin{tabular}{cccc}
\hline Samples & Formulations & Gum Arabic - GA (\%) & Maltodextrin - MD (\%) \\
\hline 1 & $100 \mathrm{GA}$ & 100 & 0 \\
\hline 2 & $75 \mathrm{MD}-25 \mathrm{GA}$ & 25 & 75 \\
\hline 3 & $100 \mathrm{MD}$ & 0 & 100 \\
\hline
\end{tabular}

Wall material powders were hydrated in deionized water for about 12 hours under refrigeration $\left(10-12{ }^{\circ} \mathrm{C}\right.$ ), then dissolved in $900 \mathrm{~mL}$ of deionized water at $60-70{ }^{\circ} \mathrm{C}$, and homogenized (TE 102, Tecnal, Piracicaba, São Paulo, Brazil) at 20,000 rpm for 30 minutes. Then, $10 \mathrm{~mL}$ of centrifuged Pequi oil was added to each formulation, and the mixtures were homogenized at 20,000 rpm for 5 min to obtain a homogeneous emulsion. Pequi oil was centrifuged (UV-5100, Tecnal, Piracicaba, São Paulo, Brazil) at 3,000 rpm for 5 min to remove suspended solids and prevent clogging of the spray drying nozzles.

Pequi oil emulsions were spray-dried using a laboratory-scale spray dryer (MSD 0.5, LabMaq, Ribeirão Preto, São Paulo, Brazil) equipped with a two-fluid nozzle (1.0 mm diameter orifice). Spray-drying conditions were as follows: inlet air temperature of $120 \pm 3{ }^{\circ} \mathrm{C}$, atomization air flow rate of $120,000 \mathrm{~L} / \mathrm{h}$, air flow rate of $1,800 \mathrm{~L} / \mathrm{h}$, feed flow rate of $0.50 \mathrm{~L} / \mathrm{h}$, and compressed air pressure of 2 to 4 bar.

Microparticles were stored in hermetically sealed plastic pots under refrigeration $\left(4-7^{\circ} \mathrm{C}\right)$ until use.

\subsection{Physicochemical characterization of pequi oil emulsions and microparticles}

Pequi oil emulsions were characterized for droplet size, polydispersity index, and zeta potential, whereas the microparticles were subjected to analyses of water activity, moisture content, wettability, encapsulation efficiency, antioxidant capacity, color, and Scanning Electron Microscopy (SEM). All analyses were carried out in triplicate.

\subsubsection{Droplet size and polydispersity index of pequi oil emulsions}

Droplet size was determined by laser diffraction (Mastersizer Hydro 2000 MU, Malvern Instruments, United Kingdom). Emulsions ( $1.0 \mathrm{~g}$ ) were suspended in $100 \mathrm{~mL}$ of deionized water, and $1 \mathrm{~mL}$ of the suspension was placed in a polycarbonate cuvette (DTS1060C). The PDI was used 
to describe droplet size distribution. Droplet diameter and PDI were calculated as the mean of three measurements.

\subsubsection{Zeta potential}

In order to determine the electrical charge on the surface of the reconstituted emulsions, $1 \mathrm{~g}$ of emulsions were diluted in $50 \mathrm{~mL}$ of deionized water. The measurements were performed in a microelectrophoresis chamber on a Zetasizer Nano ZS (Malvern Instruments, United Kingdom). Measurements were taken in triplicate.

\subsubsection{Moisture content and water activity}

Moisture content was determined by gravimetric method, using $1 \mathrm{~g}$ in an oven at $105^{\circ} \mathrm{C}$, until constant weight (Association of Official Analytical Chemists, 2005). Water activity (Aw) was measured at $25^{\circ} \mathrm{C}$ using a dew-point hygrometer (4TE, AquaLab, Pullman, WA, USA).

\subsubsection{Wettability}

About $1 \mathrm{~g}$ of sample was sprinkled into a flask containing $0.1 \mathrm{~L}$ of deionized water at $25{ }^{\circ} \mathrm{C}$, without stirring. The time required for the last particle to submerge was recorded and used as a measure of wettability (Fuchs et al., 2006).

\subsubsection{Encapsulation efficiency}

Encapsulation efficiency was determined by the method of Bae \& Lee (2008), with modifications. Hexane $(10 \mathrm{~mL})$ and $1 \mathrm{~g}$ of microparticles were added to glass vials, manually shaken for $2 \mathrm{~min}$ at ambient temperature, and filtered through Whatman $\mathrm{n}^{\mathrm{o}} 1$ filter paper. The residual powder was rinsed twice with $10 \mathrm{~mL}$ of hexane and dried to constant weight at $60{ }^{\circ} \mathrm{C}$. Surface oil content (non-encapsulated oil) was calculated as the percentage difference in sample weight before and after extraction, and the total oil was assumed to be equal to the initial oil (Carvalho et al., 2014). Encapsulation Efficiency (EE) was determined using Equation 1:

$$
E E(\%)=\left[\frac{\text { Oil } l_{\text {total }}-\text { Oil } l_{\text {surface }}}{\text { Oil } l_{\text {total }}}\right] \times 100
$$

where Oil $_{\text {total }}$ is the total oil content and Oil $_{\text {surface }}$ is the content of non-encapsulated oil on the surface of microparticles.

\subsubsection{Antioxidant capacity of pequi oil and microencapsulated Pequi oil}

Antioxidant capacity was determined by the 1,1-diphenyl-2-picrylhydrazyl (DPPH) method, adapted from Brand-Williams et al. (1995). Briefly, $6 \mu \mathrm{L}$ of sample (Pequi oil or microencapsulated Pequi oil) was mixed with $244 \mu \mathrm{L}$ of an ethanolic solution of DPPH $(0.024 \mathrm{~g} / \mathrm{L})$. After 30 minutes in the dark at room temperature, absorbance was measured at $515 \mathrm{~nm}$ using a microplate reader (Spectramax $^{\circledR}$, San Jose, CA, USA). Readings were performed in triplicate.

DPPH radical scavenging activity was expressed as percentage inhibition (I), calculated by Equation 2.

$$
I=\left[\frac{A_{0}-A_{t}}{A_{0}}\right] \times 100
$$

where $A_{0}$ and $A_{t}$ are the absorbance of the control and sample, respectively. 
Percentage inhibition values were plotted against a standard curve of Trolox (10 to $100 \mathrm{mg} / \mathrm{L}$, $\left.\mathrm{R}^{2}=0.9920\right)$. Antioxidant capacity results are expressed as $\mu \mathrm{mol}$ Trolox equivalents/g dry extract.

\subsubsection{Color}

The color of pequi oil microparticles was determined by using the spectrophotometer CM5 - Konica Minolta (Osaka, Japan). The CIELab color scale was used to measure the $\mathrm{L}^{*}, \mathrm{a}^{*}$ and $\mathrm{b}^{*}$ parameters, where $\mathrm{L}^{*}$ ranges from 0 (black) to 100 (white), $\mathrm{a}^{*}$ shows the variation from green $\left(-a^{*}\right)$ to red $\left(+a^{*}\right)$ and $b^{*}$ varies from blue $\left(-b^{*}\right)$ to yellow $\left(+b^{*}\right)$. From these parameters, the cylindrical coordinates chroma $\left(\mathrm{C}^{*}\right)$ and hue angle $\left(\mathrm{H}^{\circ}\right)$ were calculated by the Equations 3 and 4, respectively.

$$
\begin{aligned}
& C^{*}=\sqrt{\left(a^{* 2}+b^{* 2}\right)} \\
& H^{\circ}=\tan ^{-1}\left(\frac{b^{*}}{a^{*}}\right)
\end{aligned}
$$

\subsubsection{Scanning Electron Microscopy (SEM)}

The ultrastructure of pequi oil microparticles was examined by SEM. Samples were mounted on stubs, by using sputter coating in sample preparation with gold under vacuum, and observed under a SEM (VEGA LMH, TESCAN, Kohoutovice, Czech Republic) at an accelerating voltage of $30 \mathrm{kV}$ and magnification of $10,000 \mathrm{X}$.

\subsection{Statistical analysis}

A Completely Randomized Design (CRD) was carried out with three replications. Normally distributed data were subjected to Analyses of Variance (ANOVA), followed by Tukey's test $(p<0.05)$ using SISVAR version 5.6 (SISVAR ${ }^{\circledR}$, Brazil).

\section{Results and discussion}

\subsection{Droplet size emulsions}

The mean droplet size correlates well with the encapsulation efficiency; seeing that a smaller mean droplet size is usually consistent with higher encapsulation efficiency, resulting in minimum surface oil and a reduction in lipid oxidation rate (Jafari et al., 2008; Chang et al., 2020). Smaller droplet sizes are desirable, since larger sizes result in poor encapsulation efficiency (Böger et al., 2018; Linke et al., 2017).

In this study, the droplet size of pequi oil emulsions prepared with 25:75 (w/w) gum Arabic and maltodextrin, $100 \%$ gum Arabic, and 100\% maltodextrin was 2.67, 4.63, and $8.96 \mu \mathrm{m}$, respectively. These values indicate that use of different wall materials had significant influence $(p<0.05)$ on emulsions droplet size. According to Shamaei et al. (2016), the difference in the molecular structure and physicochemical properties of wall material constituents, such as surface activity and molecular weight, affects the emulsion droplet size.

The largest droplet size was obtained using maltodextrin as encapsulanting agent $(8.96 \mu \mathrm{m})$, while the emulsion prepared from the maltodextrin and gum Arabic mixture showed the smallest one (2.67). The largest diameter of the droplets may be related to the greater instability of this emulsion, which may have caused the rapid coalescence of droplets after the homogenisation process (Carvalho et al, 2014). 


\subsection{Polydispersity index and zeta potential}

The PDI represents particle size distribution of the droplets; values lower than 0.3 indicate a stable emulsion with uniform particle size distribution, whereas values greater than 0.3 show that particle size is more widely distributed (Hsu, 2016; Zhang et al., 2015).

The emulsion formulated with gum Arabic showed the lowest PDI $(p<0.05)$, and the emulsion prepared using maltodextrin or a mixture of gum Arabic and maltodextrin did not vary in PDI $(p>0.05$; Table 2). All emulsions were found to have a wide droplet size distribution, as PDI values were higher than 0.3 . High polydispersity is a characteristic of particles obtained by spray drying because during spraying the droplets do not have uniform sizes (Toledo Hijo et al., 2014).

Table 2. Polydispersity index (PDI) and zeta potential of pequi oil emulsions prepared with different proportions of gum Arabic (GA) and maltodextrin (MD) as wall materials.

\begin{tabular}{ccc}
\hline Wall Compositions & Zeta Potencial $(\mathbf{m V})$ & PDI \\
\hline $100 \mathrm{GA}$ & $-10.50 \pm 0.08^{\mathrm{b}}$ & $0.46 \pm 0.10^{\mathrm{b}}$ \\
\hline $75 \mathrm{MD}-25 \mathrm{GA}$ & $-7.30 \pm 0.39^{\mathrm{c}}$ & $0.89 \pm 0.13^{\mathrm{a}}$ \\
\hline $100 \mathrm{MD}$ & $-4.27 \pm 0.00^{\mathrm{a}}$ & $0.83 \pm 0.00^{\mathrm{ab}}$ \\
\hline
\end{tabular}

Values with different letters in the same column differ significantly $(p<0.05)$.

Zeta potential is an important physicochemical parameter related to the stability of microencapsulated products. Droplets with large zeta potential repel each other, and consequently improve the solution stability (Tantra et al., 2010). According to Honary \& Zahir (2013), emulsions with zeta potentials higher than $|30| \mathrm{mV}$ are stable, with zeta potentials in the range of 0 to $\pm 5 \mathrm{mV}$ are unstable and tend to coagulate, and with zeta potentials of \pm 5 to $\pm 30 \mathrm{mV}$ are slightly stable.

Emulsions prepared with gum Arabic or gum Arabic and maltodextrin had a more stable behavior than those prepared with maltodextrin only (Table 2). Maltodextrin emulsions are likely to coagulate, as their zeta potential values were between 0 and $-5 \mathrm{mV}$.

\subsection{Moisture content and water activity}

Moisture content and water activity are critical factors affecting the processing, flowability, handling, and shelf life of microencapsulated oil powders (Felix et al., 2017; Sanchez-Reinoso \& Gutiérrez, 2017).

Botrel et al. (2012) reported that low values of water activity and moisture may contribute to powder conservation during storage and may prevents possible changes in the physicochemical properties of microparticles. According to Fennema (2009) and Quispe-Condori et al. (2011), dry foods should have a moisture content of $3 \%$ to $10 \%$ and a water activity of less than 0.30 to maintain stability throughout shelf life. In this study, the moisture content of Pequi oil microparticles varied from $3.33 \%$ to $3.59 \%$, and water activity ranged from 0.05 to 0.12 (Table 3). These results indicate that dried microparticles of pequi oil have characteristics that can contribute to good stability during storage and handling.

Table 3. Water activity and moisture content of pequi oil microparticles prepared with different proportions of gum Arabic (GA) and maltodextrin (MD) as wall materials.

\begin{tabular}{ccc}
\hline Wall Compositions & Water activity $\left(\mathbf{A}_{\mathbf{w}}\right)$ & Moisture content (\%) \\
\hline $100 \mathrm{GA}$ & $0.05 \pm 0.00^{\mathrm{c}}$ & $3.55 \pm 0.00^{\mathrm{a}}$ \\
\hline $75 \mathrm{MD}-25 \mathrm{GA}$ & $0.12 \pm 0.01^{\mathrm{a}}$ & $3.59 \pm 0.00^{\mathrm{a}}$ \\
\hline $100 \mathrm{MD}$ & $0.09 \pm 0.01^{\mathrm{b}}$ & $3.33 \pm 0.01^{\mathrm{a}}$ \\
\hline
\end{tabular}

Values with different letters in the same column differ significantly $(p<0.05)$. 
Costa et al. (2016) produced pequi oil microcapsules by spray drying using a 25:50:25 mixture of gum Arabic, modified starch, and maltodextrin as wall material. The microcapsules had a moisture content of $3.46 \%$, similar to the observed in our study, and a water activity of 0.50 , about $24 \%$ higher than that found here.

Santana et al. (2013a), in analyzing the physicochemical characteristics of microparticles of Pequi pulp extract produced using gum Arabic as an encapsulating agent, observed a moisture content of $0.3 \%$ to $1.9 \%$ and water activity of 0.07 to 0.17 . In a later study, the authors prepared spray-dried Pequi pulp microparticles using maltodextrin DE-10 as encapsulant and found lower moisture content $(0.25-1.43 \%)$ and similar water activity $(0.09$ to 0.21$)$ values to those observed in this study (Santana et al., 2016).

Moisture content did not vary significantly $(p>0.05)$ among formulations, showing that wall material composition did not affect moisture. However, microparticles differed in water activity $(p<0.05)$; while the lowest values were observed in microparticles prepared with gum Arabic.

\subsection{Wettability}

Wettability is the ability of a liquid to maintain contact with a solid surface. It is an important physical property of microparticles because it is directly associated with their ability to be reconstituted in an aqueous solution (Felix et al., 2017; Fernandes et al., 2016).

The wettability of microparticles prepared using 25:75 (w/w) gum Arabic and maltodextrin, $100 \%$ gum Arabic, and 100\% maltodextrin was $16.36 \pm 0.57,18.57 \pm 1.99$, and $17.44 \pm 3.46 \mathrm{~min}$, respectively. No significant differences $(p>0.05)$ in wettability were observed; therefore, wall material composition had no effect on the wettability of Pequi oil microparticles.

In the study of Costa et al. (2016), the wettability of microencapsulated pequi oil was 15.54 minutes, similar to that found in the current study. Babassu, another fruit from the Cerrado biome, was microencapsulated by spray drying and had a wettability of $12.02 \mathrm{~min}$ (Santana et al., 2013b).

\subsection{Encapsulation efficiency}

Encapsulation efficiency varied from $79.17 \%$ to $84.20 \%$, as shown in Table 4 . Wall material composition greatly influences the encapsulation efficiency of oils during spray drying (Mohammed et al., 2017). Gum Arabic is widely used to encapsulate oils because of its good emulsifying properties and volatile retention, leading to high encapsulation efficiency (Jafari et al., 2008). However, in this study, microparticles produced with gum Arabic as the sole encapsulant had low encapsulation efficiency $(79.17 \%)$, not differing $(p>0.05)$ from that of microparticles prepared with gum Arabic and maltodextrin at 25:75 (w/w).

Table 4. Encapsulation efficiency of pequi oil microparticles prepared with different proportions of gum Arabic (GA) and maltodextrin (MD) as wall materials.

\begin{tabular}{cc}
\hline Wall compositions & Encapsulation efficiency (\%) \\
\hline $100 \mathrm{GA}$ & $79.17 \pm 0.51^{\mathrm{b}}$ \\
\hline $75 \mathrm{MD}-25 \mathrm{GA}$ & $80.26 \pm 0.14^{\mathrm{b}}$ \\
\hline $100 \mathrm{MD}$ & $84.20 \pm 1.50^{\mathrm{a}}$ \\
\hline
\end{tabular}

Values with different letters in the same column differ significantly $(p<0.05)$.

The encapsulation efficiency obtained with gum Arabic was similar to the reported by Sarkar et al. (2013) for microencapsulated mint oil (80.66\%). Böger et al. (2018) found that partially replacing gum Arabic with maltodextrin did not significantly affect $(p<0.05)$ the encapsulation efficiency of grape seed oil. 
According to Akhavan Mahdavi et al. (2016), the use of maltodextrin as encapsulant reduces encapsulation efficiency, probably because of its low film-forming capacity and lack of emulsification properties. In contrast, we found that microparticles prepared using $100 \%$ maltodextrin as wall material showed the highest encapsulation efficiency (84.20\%). A similar result was obtained by Ramakrishnan et al. (2018) for microcapsules prepared with tamarillo carotenoids and maltodextrin as encapsulant (84.77\%). Kang et al. (2019) showed that maltodextrin alone led to a higher encapsulation efficiency of chlorophylls than 5:5 or 3:7 mixtures of gum Arabic and maltodextrin as wall material. The authors argued that maltodextrin's thermal protection may have increased encapsulation efficiency.

\subsection{Antioxidant capacity of pequi oil and microencapsulated pequi oil}

The antioxidant capacity of all samples ranged from 28.20 to $28.78 \mu$ mol Trolox equivalents/g dry extract (Table 5). Non-encapsulated Pequi oil showed the highest antioxidant capacity, followed by microparticles prepared with gum Arabic and those prepared with maltodextrin. A decrease in antioxidant activity with spray drying is expected, as compounds are subjected to high temperatures $\left(>65^{\circ} \mathrm{C}\right.$ ) (Medina-Torres et al., 2016). Corrêa-Filho et al. (2019) and Santiago-Adame et al. (2015) observed this effect in the microencapsulation of $\beta$-carotene with gum Arabic and cinnamon infusions with maltodextrin, respectively.

Table 5. Antioxidant capacity of pequi oil and pequi oil microparticles prepared with different proportions of gum Arabic (GA) and maltodextrin (MD) as wall materials.

\begin{tabular}{cc}
\hline Samples & DPPH $(\boldsymbol{\mu m o l}$ of Trolox equivalent (T.E) / g of dry extract) \\
\hline Pequi oil & $28.78 \pm 0.01^{\mathrm{a}}$ \\
\hline $100 \mathrm{GA}$ & $28.71 \pm 0.01^{\mathrm{b}}$ \\
\hline $75 \mathrm{MD}-25 \mathrm{GA}$ & $28.68 \pm 0.02^{\mathrm{b}}$ \\
\hline $100 \mathrm{MD}$ & $28.20 \pm 0.01^{\mathrm{c}}$ \\
\hline
\end{tabular}

Values with different letters in the same column differ significantly $(p<0.05)$. DPPH $=1,1$-diphenyl-2-picrylhydrazyl.

Despite the loss after atomization, it can be observed that the loss of antioxidant capacity was not so large, and the samples that used gum Arabic as wall material showed better antioxidant capacity values than the microparticles produced only with maltodextrin.

\subsection{Color}

Table 6 presents the color parameters of microencapsulated pequi oil. Significant differences $(p<0.05)$ were observed among the samples. All microparticles showed high $\mathrm{L}^{*}$ (lightness) values, particularly microparticles produced with maltodextrin. According to Nunes et al. (2015), lightness of the microparticles tends to increase with the augmentation of maltodextrin concentration, whereas $a^{*}$ decreases. Positive values of $a^{*}$ and $b^{*}$ were observed for most microparticles, indicating that the products had red/yellow color. Costa et al. (2016) reported similar results: $\mathrm{a}^{*}$ and $\mathrm{b}^{*}$ values of Pequi oil microparticles were respectively 4.71 and 12.04. Alves et al. (2017) prepared microparticles with an $a^{*}$ value of 16.91 and $b^{*}$ value of 42.11 . Positive $b^{*}$ value is associated with the presence of yellow carotenoids (e.g., violaxanthin), which are the major pigments in microencapsulated Pequi extracts (Alves et al., 2017). 
Table 6. Color parameters of pequi oil microparticles prepared with different proportions of gum Arabic (GA) and maltodextrin (MD) as wall materials.

\begin{tabular}{cccccc}
\hline Wall compositions & $\mathbf{L}^{*}$ & $\mathbf{a}^{*}$ & $\mathbf{b}^{*}$ & $\mathbf{H}^{\circ}$ & $\mathbf{C}^{*}$ \\
\hline 100 GA & $80.28 \pm 0.49^{\mathrm{c}}$ & $2.01 \pm 0.04^{\mathrm{c}}$ & $13.50 \pm 0.09^{\mathrm{b}}$ & $81.32 \pm 0.14^{\mathrm{c}}$ & $13.30 \pm 0.09^{\mathrm{b}}$ \\
\hline 25 GA: 75 MD & $87.80 \pm 0.33^{\mathrm{a}}$ & $1.11 \pm 0.03^{\mathrm{a}}$ & $10.59 \pm 0.08^{\mathrm{a}}$ & $84.00 \pm 0.12^{\mathrm{a}}$ & $10.65 \pm 0.09^{\mathrm{a}}$ \\
\hline 100 MD & $96.20 \pm 0.17^{\mathrm{b}}$ & $0.49 \pm 0.04^{\mathrm{b}}$ & $9.94 \pm 0.44^{\mathrm{a}}$ & $87.18 \pm 0.31^{\mathrm{b}}$ & $9.95 \pm 0.44^{\mathrm{a}}$ \\
\hline
\end{tabular}

Values with different letters in the same column differ significantly $(p<0.05) . \mathrm{L}^{*}=$ lightness; $\mathrm{a}^{*}=$ redness; $\mathrm{b}^{*}=$ yellowness; $\mathrm{H}^{\circ}=$ hue angle; $\mathrm{C}^{*}=$ chroma.

High values of tone $\left(\mathrm{H}^{\circ}\right)$ were obtained for all the microparticles as a result of their low $\mathrm{a}^{*}$ and high $b^{*}$ values. The color saturation $\left(C^{*}\right)$ did not vary $(p>0.05)$ between samples produced with the 25:75 (w/w) mixture of gum Arabic and maltodextrin or maltodextrin only. Microparticles prepared with gum Arabic had significantly higher $C^{*}$ values, showing that wall material composition influenced color intensity.

\subsection{Scanning electron microscopy}

Cracked or damaged particles can compromise the stability of the encapsulated material; therefore, it is important to evaluate the ultrastructure of microparticles (Campelo et al., 2017).

The SEM images revealed that microparticles were not collapsed and did not have fissures or cracks. Furthermore, the particles presented irregular shape with circular predominance, depressions and concavities (Figure 1).

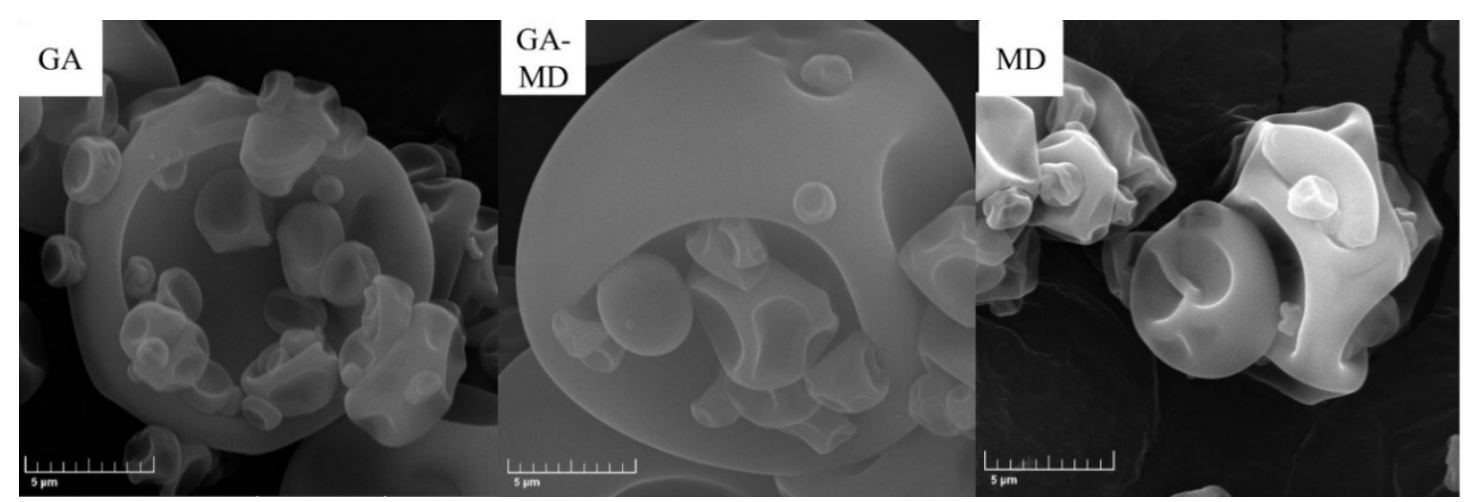

Figure 1. Scanning electron images of pequi oil microparticles prepared using gum Arabic (GA), maltodextrin (MD), or a 25:75 (w/w) mixture of gum Arabic and maltodextrin (GA-MD).

Other point observed in all samples, was the agglomeration of the particles. Particle agglomeration increased with maltodextrin concentration, probably as a result of the coalescence of smaller particles with larger particles (Bhandari et al., 1992).

\section{Conclusion}

This study discussed the influence of wall material composition on the characteristics of pequi oil microparticles obtained by spray drying.

Pequi oil microencapsulated with gum Arabic had lower water activity, higher antioxidant capacity, and lower lightness and hue angle, whereas microparticles prepared with maltodextrin had higher encapsulation efficiency. Spray drying using a 25:75 mixture of gum Arabic and maltodextrin as wall material resulted in smaller droplet size and lower zeta potential. Wall material composition did not affect moisture content or wettability. 
All microparticles had satisfactory encapsulation efficiency, water activity, moisture content, and wettability, which are important characteristics for storage and handling stability.

\section{Acknowledgements}

Coordenação de Aperfeiçoamento de Pessoal de Nível Superior (CAPES); Fundação de Amparo à Pesquisa do Estado de Minas Gerais (FAPEMIG) and, Universidade Federal dos Vales Jequitinhonha e Mucuri (UFVJM).

\section{References}

Aguilar, E. C., Jascolka, T. L., Teixeira, L. G., Lages, P. C., Ribeiro, A. C. C., Vieira, E. L. M., Peluzio, M. C. G., \& Alvarez-Leite, J. I. (2012). Paradoxical effect of a pequi oil-rich diet on the development of atherosclerosis: Balance between antioxidant and hyperlipidemic properties. Brazilian Journal of Medical and Biological Research, 45(7), 601609. PMid:22570088. http://dx.doi.org/10.1590/S0100-879X2012007500074

Akhavan Mahdavi, S., Jafari, S. M., Assadpoor, E., \& Dehnad, D. (2016). Microencapsulation optimization of natural anthocyanins with maltodextrin, gum Arabic and gelatin. International Journal of Biological Macromolecules, 85, 379385. PMid:26772915. http://dx.doi.org/10.1016/j.ijbiomac.2016.01.011

Alves, A. I., Rodrigues, M. Z., Ribeiro Pinto, M. R. M., Lago Vanzela, E. S., Stringheta, P. C., Perrone, Í. T., \& Ramos, A. M. (2017). Morphological characterization of pequi extract microencapsulated through spray drying. International Journal of Food Properties, 2912, 1-8. http://dx.doi.org/10.1080/10942912.2017.1343344

Association of Official Analytical Chemists - AOAC. (2005). Official methods 955.04. Gaithersburg: AOAC.

Bae, E. K., \& Lee, S. J. (2008). Microencapsulation of avocado oil by spray-drying using whey protein and maltodextrin. Journal of Microencapsulation, 25(8), 549-560. http://dx.doi.org/10.1080/02652040802075682

Bhandari, B. R., Dumoulin, E. D., Richard, H. M. J., Noleau, I., \& Lebert, A. M. (1992). Flavor encapsulation by spray drying: Application and linalyl acetate. Food Reviews International, 57(1), 217-221.

http://dx.doi.org/10.1080/87559128909540848

Böger, B. R., Georgetti, S. R., \& Kurozawa, L. E. (2018). Microencapsulation of grape seed oil by spray drying. Food Science and Technology, 38(2), 263-270. http://dx.doi.org/10.1590/fst.04417

Botrel, D. A., Borges, S. V., Fernandes, R. V. B., Viana, A. D., Costa, J. M. G., \& Marques, G. R. (2012). Evaluation of spray drying conditions on properties of microencapsulated oregano essential oil. International Journal of Food Science \& Technology, 47(11), 2289-2296. http://dx.doi.org/10.1111/j.1365-2621.2012.03100.x

Brand-Williams, W., Cuvelier, M., \& Berset, C. (1995). Use of a free radical method to evaluate antioxidant activity. Journal of Food Science and Technology, 28(1), 25-30.

Campelo, P. H., do Carmo, E. L., Zacarias, R. D., Yoshida, M. I., Ferraz, V. P., de Barros Fernandes, R. V., Botrel, D. A., \& Borges, S. V. (2017). Effect of dextrose equivalent on physical and chemical properties of lime essential oil microparticles. Industrial Crops and Products, 102, 105-114. http://dx.doi.org/10.1016/j.indcrop.2017.03.021

Carneiro, H. C. F., Tonon, R. V., Grosso, C. R. F., \& Hubinger, M. D. (2013). Encapsulation efficiency and oxidative stability of flaxseed oil microencapsulated by spray drying using different combinations of wall materials. Journal of Food Engineering, 115(4), 443-451. http://dx.doi.org/10.1016/j.jfoodeng.2012.03.033

Carvalho, A. G. S., Silva, V. M., \& Hubinger, M. D. (2014). Microencapsulation by spray drying of emulsified green coffee oil with two-layered membranes. Food Research International, 61, 236-245. http://dx.doi.org/10.1016/j.foodres.2013.08.012

Chang, H. W., Tan, T. B., Tan, P. Y., Nehdi, I. A., Sbihi, H. M., \& Tan, C. P. (2020). Microencapsulation of fish oil-inwater emulsion using thiol-modified $\beta$-lactoglobulin fibrils-chitosan complex. Journal of Food Engineering, 264, 109680. http://dx.doi.org/10.1016/j.jfoodeng.2019.07.027

Corrêa-Filho, L. C., Lourenço, M. M., Moldão-Martins, M., \& Alves, V. D. (2019). Microencapsulation of $\beta$-Carotene by spray drying: effect of wall material concentration and drying inlet temperature. International Journal of Food Sciences, 2019, 1-12. https://doi.org/10.1155/2019/8914852

Costa, J. M. G., Hijo, A. A. C. T., Silva, E. K., Borges, S. V., \& Marques, G. R. (2016). Agregando valor a las frutas del cerrado brasileño: Encapsulación de aceite de pequi a través del secado por atomización. Engenharia na Agricultura, 23(3), 197-204. http://dx.doi.org/10.13083/1414-3984/reveng.v24n3p197-204

Di Battista, C. A., Constenla, D., Ramírez-Rigo, M. V., \& Piña, J. (2015). The use of Arabic gum, maltodextrin and surfactants in the microencapsulation of phytosterols by spray drying. Powder Technology, 286, 193-201. http://dx.doi.org/10.1016/j.powtec.2015.08.016

Felix, P. H. C., Birchal, V. S., Botrel, D. A., Marques, G. R., \& Borges, S. V. (2017). Physicochemical and thermal stability of microcapsules of cinnamon essential oil by spray drying. Journal of Food Processing and Preservation, 41(3), e12919. http://dx.doi.org/10.1111/jppp.12919

Fennema, O. R. (2009). Food chemistry (3rd ed., pp. 17-94). New York: Marcel Dekker. 
Fernandes, R. V. B., Botrel, D. A., Silva, E. K., Borges, S. V., Oliveira, C. R., Yoshida, M. I., Feitosa, J. P. A., \& Paula, R. C. M. (2016). Cashew gum and inulin: New alternative for ginger essential oil microencapsulation. Carbohydrate Polymers, 153, 133-142. PMid:27561480. http://dx.doi.org/10.1016/j.carbpol.2016.07.096

Fuchs, M., Turchiuli, C., Bohin, M., Cuvelier, M. E., Ordonnaud, C., Peyrat-Maillard, M. N., \& Dumoulin, E. (2006). Encapsulation of oil in powder using spray drying and fluidised bed agglomeration. Journal of Food Engineering, 75(1), 27-35. http://dx.doi.org/10.1016/j.jfoodeng.2005.03.047

Gupta, C., Chawla, P., Arora, S., Tomar, S. K., \& Singh, A. K. (2015). Microencapsulation with blend of gum arabic, maltodextrin and modified starch using modified solvent evaporation method: Milk fortification. Food Hydrocolloids, 43, 622-628. http://dx.doi.org/10.1016/j.foodhyd.2014.07.021

Honary, S., \& Zahir, F. (2013). Effect of zeta potential on the properties of nano-drug delivery systems: A review (Part 1). Tropical Journal of Pharmaceutical Research, 12(2), 265-273. http://dx.doi.org/10.4314/tjpr.v12i2.19

Hsu, J.-C. (2016). U.S. Patent No. US9498412B2. Method for producing microcapsules with a sun protection effect. United States.

Jafari, S. M., Assadpoor, E., He, Y., \& Bhandari, B. (2008). Encapsulation efficiency of food flavours and oils during spray drying. Drying Technology, 26(7), 816-835. http://dx.doi.org/10.1080/07373930802135972

Kang, Y. R., Lee, Y. K., Kim, Y. J., \& Chang, Y. H. (2019). Characterization and storage stability of chlorophylls microencapsulated in different combination of gum Arabic and maltodextrin. Food Chemistry, 272, 337-346. PMid:30309553. http://dx.doi.org/10.1016/j.foodchem.2018.08.063

Linke, A., Anzmann, T., Weiss, J., \& Kohlus, R. (2017). Advanced characterisation of encapsulated lipid powders regarding microstructure by time domain-nuclear magnetic resonance. Journal of Microencapsulation, 34(2), 140150. PMid:28298154. http://dx.doi.org/10.1080/02652048.2017.1300198

Medina-Torres, L., Santiago-Adame, R., Calderas, F., Gallegos-Infante, J. A., González-Laredo, R. F., RochaGuzmán, N. E., Núñez-Ramírez, D. M., Bernad-Bernad, M. J., \& Manero, O. (2016). Microencapsulation by spray drying of laurel infusions (Litsea glaucescens) with maltodextrin. Industrial Crops and Products, 90, 1-8. http://dx.doi.org/10.1016/j.indcrop.2016.06.009

Mendonça, K. S., Corrêa, J. L. G., Junqueira, J. R. J., Cirillo, M. A., Figueira, F. V., \& Carvalho, E. E. N. (2017). Influences of convective and vacuum drying on the quality attributes of osmo-dried pequi (Caryocar brasiliense Camb.) slices. Food Chemistry, 224, 212-218. PMid:28159258. http://dx.doi.org/10.1016/j.foodchem.2016.12.051

Mohammed, N. K., Tan, C. P., Manap, Y. A., Alhelli, A. M., Shobirin, A., \& Hussin, M. (2017). Process conditions of spray drying microencapsulation of Nigella sativa oil. Powder Technology, 315, 1-14. http://dx.doi.org/10.1016/j.powtec.2017.03.045

Nunes, G. L. B., Boaventura, B. C. B., Pinto, S. S., Verruck, S., Murakami, F. S., Prudêncio, E. S., \& Amboni, R. D. C. (2015). Microencapsulation of freeze concentrated llex paraguariensis extract by spray drying. Journal of Food Engineering, 151, 60-68. http://dx.doi.org/10.1016/j.jfoodeng.2014.10.031

Pereira, K. C., Ferreira, D. C. M., Alvarenga, G. F., Pereira, M. S. S., Barcelos, M. C. S., \& Costa, J. M. G. (2018). Microencapsulação e liberação controlada por difusão de ingredientes alimentícios produzidos através da secagem por atomização: Revisão. Brazilian Journal of Food Technology, 21, e2017083. http://dx.doi.org/10.1590/19816723.08317

Pessoa, A. S., Podestá, R., Block, J. M., Franceschi, E., Dariva, C., \& Lanza, M. (2015). Extraction of pequi (Caryocar coriaceum) pulp oil using subcritical propane: Determination of process yield and fatty acid profile. The Journal of Supercritical Fluids, 101, 95-103. http://dx.doi.org/10.1016/..supflu.2015.03.006

Quispe-Condori, S., Saldaña, M. D. A., \& Temelli, F. (2011). Microencapsulation of flax oil with zein using spray and freeze drying. Lebensmittel-Wissenschaft + Technologie, 44(9), 1880-1887. http://dx.doi.org/10.1016/j.Iwt.2011.01.005

Ramakrishnan, Y., Adzahan, N. M., Yusof, Y. A., \& Muhammad, K. (2018). Effect of wall materials on the spray drying efficiency, powder properties and stability of bioactive compounds in tamarillo juice microencapsulation. Powder Technology, 328, 406-414. http://dx.doi.org/10.1016/j.powtec.2017.12.018

Sanchez-Reinoso, Z., \& Gutiérrez, L.-F. (2017). Effects of the emulsion composition on the physical properties and oxidative stability of sacha inchi (Plukenetia volubilis L.) oil microcapsules produced by spray drying. Food and Bioprocess Technology, 10(7), 1354-1366. http://dx.doi.org/10.1007/s11947-017-1906-3

Santana, A. A., Kurozawa, L. E., Oliveira, R. A., \& Park, K. J. (2013a). Influence of process conditions on the physicochemical properties of pequi powder produced by spray drying. Drying Technology, 31(7), 825-836. http://dx.doi.org/10.1080/07373937.2013.766619

Santana, A. A., Oliveira, R. A., Pinedo, A. A., Kurozawa, L. E., \& Park, K. J. (2013b). Microencapsulation of babassu coconut milk. Food Science and Technology, 33(4), 737-744. http://dx.doi.org/10.1590/S0101-20612013000400020

Santana, A. A., Oliveira, R. A., Kurozawa, L. E., \& Park, K. J. (2014). Microencapsulation of pequi pulp by spray drying: Use of modified starches as encapsulating agent. Engenharia Agrícola, 34(5), 980-991. http://dx.doi.org/10.1590/S0100-69162014000500017

Santana, A., Kurozawa, L., Oliveira, R., \& Park, K. (2016). Spray drying of pequi pulp: Process performance and physicochemical and nutritional properties of the powdered pulp. Brazilian Archives of Biology and Technology, 59(0), 1-11. http://dx.doi.org/10.1590/1678-4324-2016150362 
Santiago-Adame, R., Medina-Torres, L., Gallegos-Infante, J. A., Calderas, F., González-Laredo, R. F., RochaGuzmán, N. E., Ochoa-Martínez, L. A., \& Bernad-Bernad, M. J. (2015). Spray drying-microencapsulation of cinnamon infusions (Cinnamomum zeylanicum) with maltodextrin. Lebensmittel-Wissenschaft + Technologie, 64(2), 571-577. http://dx.doi.org/10.1016/j.Iwt.2015.06.020

Sarkar, S., Gupta, S., Variyar, P. S., Sharma, A., \& Singhal, R. S. (2013). Hydrophobic derivatives of guar gum hydrolyzate and gum Arabic as matrices for microencapsulation of mint oil. Carbohydrate Polymers, 95(1), 177-182. PMid:23618256. http://dx.doi.org/10.1016/j.carbpol.2013.02.070

Shamaei, S., Seiiedlou, S. S., Aghbashlo, M., Tsotsas, E., \& Kharaghani, A. (2016). Microencapsulation of walnut oil by spray drying: Effects of wall material and drying conditions on physicochemical properties of microcapsules. Innovative Food Science \& Emerging Technologies, 39, 101-112. http://dx.doi.org/10.1016/j.ifset.2016.11.011

Tantra, R., Schulze, P., \& Quincey, P. (2010). Effect of nanoparticle concentration on zeta-potential measurement results and reproducibility. Particuology, 8(3), 279-285. http://dx.doi.org/10.1016/j.partic.2010.01.003

Toledo Hijo, A. A. C., Da Costa, J. M. G., Silva, E. K., Azevedo, V. M., Yoshida, M. I., \& Borges, S. V. (2014). Physical and thermal properties of oregano (Origanum vulgare L.) essential oil microparticles. Journal of Food Process Engineering, 38(1), 1-10. http://dx.doi.org/10.1111/jfpe.12120

Zhang, Y., Tan, C., Abbas, S., Eric, K., Xia, S., \& Zhang, X. (2015). Modified SPI improves the emulsion properties and oxidative stability of fish oil microcapsules. Food Hydrocolloids, 51, 108-117. http://dx.doi.org/10.1016/j.foodhyd.2015.05.001 